\title{
Antioxidant response and body composition of whiteleg shrimp co-cultured with Nile tilapia in recirculating aquaculture
}

\author{
Zaki Z. Sharawy ${ }^{1, *}$, Rajko Thiele ${ }^{2}$, Eman M. Abbas' ${ }^{1}$, Mohammed A. El-Magd ${ }^{3}$, \\ Mohammed S. Hassaan ${ }^{1}$, Corina Peter ${ }^{2}$, Jan Schmidt ${ }^{2}$, Reinhard Saborowski ${ }^{2}$, \\ Ashraf M. A. S. Goda ${ }^{1}$, Matthew J. Slater ${ }^{2}$ \\ ${ }^{1}$ Aquaculture Division, National Institute of Oceanography and Fisheries (NIOF), Suez, Egypt \\ ${ }^{2}$ Alfred Wegener Institute Helmholtz Centre for Polar and Marine Research, Am Handelshafen 12, 27570 Bremerhaven, \\ Germany \\ ${ }^{3}$ Department of Anatomy, Faculty of Veterinary Medicine, Kafrelsheikh University, Kafrelsheikh, Egypt
}

\begin{abstract}
Co-culture of the high-value tropical species whiteleg shrimp Litopenaeus vannamei and Nile tilapia Oreochromis niloticus may have significant commercial and environmental benefits. However, feeding regimes and holding conditions must meet the animals' nutritional requirements and minimize stress reactions. In the current study, whiteleg shrimp and a commercially important red strain of Nile tilapia were maintained in monoculture and in co-culture under controlled conditions in a recirculating aquaculture system. Shrimp in monoculture received a commercial food. Shrimp in co-culture either fed only on tilapia waste or on tilapia waste with a low supplement of commercial diet (treatment 'FSD'). To assess the metabolic stress level of shrimp, we measured the relative expression of the antioxidant-related genes $C M n S O D$ and GPX in the abdominal muscles and the activities of digestive proteinases and alkaline phosphatase in the midgut gland. Shrimp in co-culture showed significantly reduced expression of both antioxidants, indicating lower stress levels than monocultured shrimp fed a commercial diet. Digestive enzyme activities, along with hepatosomatic indices and enzyme expression patterns indicate unimpaired food utilization and excellent nutritional status in shrimp across all treatments. Final body weight was significantly higher in shrimp in both co-culture treatments, with highest growth rates in FSD shrimp. Growth rates indicate that tilapia biowaste/faeces can be used as a sole diet for high-value shrimp, irrespective of the feeding regime. Beyond known benefits such as higher yield and efficient resource use, our results show that co-culture of the 2 species is successful in terms of nutritional provision and shrimp health status.
\end{abstract}

KEY WORDS: Litopenaeus vannamei $\cdot$ Oreochromis niloticus $\cdot$ Red male tilapia $\cdot$ Antioxidantrelated genes $\cdot$ Integrated multi-trophic aquaculture $\cdot$ Digestive enzyme $\cdot$ Biowaste diet

\section{INTRODUCTION}

Co-culture, often referred to as Integrated MultiTrophic Aquaculture (IMTA), combines species with different but complementary feeding and habitat requirements to maximize productivity through the

${ }^{*}$ Corresponding author: zaki_sharawy@yahoo.com efficient occupation of physical space and utilization of resources (McGinty \& Alston 1987, Lutz 2003, Milstein et al. 2006). Such approaches make use of wastes and by-products as new food sources within the system: i.e. food remains and faeces from one species become the basic food resource of the other

(C) The authors 2017. Open Access under Creative Commons by Attribution Licence. Use, distribution and reproduction are unrestricted. Authors and original publication must be credited. 
species (Neori et al. 2004). However, maximizing the use of food and space resources must not provoke feed competition between the cultured species or result in nutritional stress, particularly in the species consuming the by-products (Chopin et al. 2001, Muangkeow et al. 2007).

Co-culture of whiteleg shrimp Litopenaeus vannamei and Nile tilapia Oreochromis niloticus is an example of a highly promising production method with potential commercial and environmental benefits (Muangkeow et al. 2007, Barraza 2010, Yuan et al. 2010, Hernández-Barraza et al. 2012, 2013, Goda et al. 2015, Henry-Silva et al. 2015, Wang \& Lu 2016, Perschbacher \& Stickney 2017). However, biotic and abiotic conditions in shrimp-tilapia co-culture systems must be optimal to ensure growth and survival. This includes the provision of an optimal diet, even if it originates from faeces of co-cultured species. Somatic measures such as hepatosomatic indices and animal growth performance and survival broadly reflect the nutritional status. The ability and the capacity to utilize the offered food can be determined using well-established assays for digestive enzyme activities and enzyme expression patterns. Hence, diet quality, in particular the protein content, as well as the size and age of animals (Lee et al. 1984) or the addition of probiotics to the diet (Wang 2007) affect the activity of midgut gland enzymes.

Animal performance in co-culture may also be affected by hidden stressors resulting from the presence or interactions between co-cultured species or related to holding conditions. Many stressors tend to result in increased production of reactive oxygen species (ROS) (Castex et al. 2010, Qiu et al. 2011). To minimize the deleterious effects of ROS, shrimp possess an enzymatic and non-enzymatic antioxidant defence system (AD) which becomes more active in response to those stressors. Some of the most important antioxidant enzymes are glutathione peroxidase (GPX), superoxide dismutase (SOD) and catalase (CAT), which are necessary to reduce high ROS levels in the tissues (García-Triana et al. 2010, Sheikhzadeh et al. 2012). If excess ROS are not neutralized by the $\mathrm{AD}$, oxidative stress-induced cellular damage and death may occur (Kassahn et al. 2009).

The antioxidant gene expression response is among the most important stress biomarkers in cultured species, as it is extremely sensitive and usually occurs earlier than those of other biomarkers at higher levels of biological organization. Previous studies have reported that the GPX and $C M n S O D$ genes contribute significantly to GPX and $S O D$ enzymatic activity and indicate its importance in the redox sys- tem regulation for L. vannamei (García-Triana et al. 2010) and tilapia (Sheikhzadeh et al. 2012). Expression of the $C M n S O D$ gene was upregulated following exposure of $L$. vannamei to acute $\mathrm{pH}$ stress (Wang et al. 2009) and hypoxia (García-Triana et al. 2010). Activities of MnSOD and CuSOD in L. vannamei (Zhou et al. 2010) and the abalone Haliotis discus (Kim et al. 2007) have been shown to increase under heat stress. In tilapia, a tendency towards higher activity of $S O D$ in muscle tissue is observed under acute cold stress (He et al. 2015).

The present experimental study was aimed at investigating whether fish and shrimp can be successfully maintained in a value-added manner in coculture treatments. The experiments were run in recirculating aquaculture systems (RAS) suited to small-scale production in developing countries. Whiteleg shrimp L. vannamei and a commercially important red strain of Nile tilapia $O$. niloticus were maintained in 2 distinct co-culture treatments and separately in monoculture for comparison. In the first co-culture treatment, only the tilapia were fed while the shrimp fed solely on fish food remains and tilapia faeces. In the second co-culture treatment, tilapia were fed with fish food, and the shrimp were provided with $25 \%$ of the recommended commercial diet. Growth, feeding efficiency and nutrition efficiency rates were determined along with digestive enzyme activity responses to investigate, in particular, the applicability of uneaten feed and faeces from tilapia as a co-culture diet for shrimp. Molecular stress markers, in particular antioxidant gene expression, were assayed in order to determine the stress status of shrimp under different feeding and holding regimes. Nutrition and stress response served as a measure for the well-being of the animals and, thus, the utility of this aquaculture approach.

\section{MATERIALS AND METHODS}

\section{Aquatic species husbandry}

Whiteleg shrimp (PL12) were obtained from SIS commercial hatchery in Miami, Florida (USA). Male Nile tilapia of a commercially important red strain (red natural male Nile tilapia, Red $\mathrm{NMT}^{\mathrm{TM}}$; for simplicity, hereafter referred to as [red] tilapia) were purchased from Til-Aqua International (The Netherlands; for details on the production of all-male tilapia see www.til-aqua.com). The experiments were carried out at the Centre for Aquaculture Research (ZAF) within the Alfred Wegener Institute, Helmholtz Cen- 
Fig. 1. Cross-sectional view of a whiteleg shrimp Litopenaeus vannamei and Nile tilapia Oreochromis niloticus co-culture unit showing the different experimental system components. RAS: recirculating aquaculture system

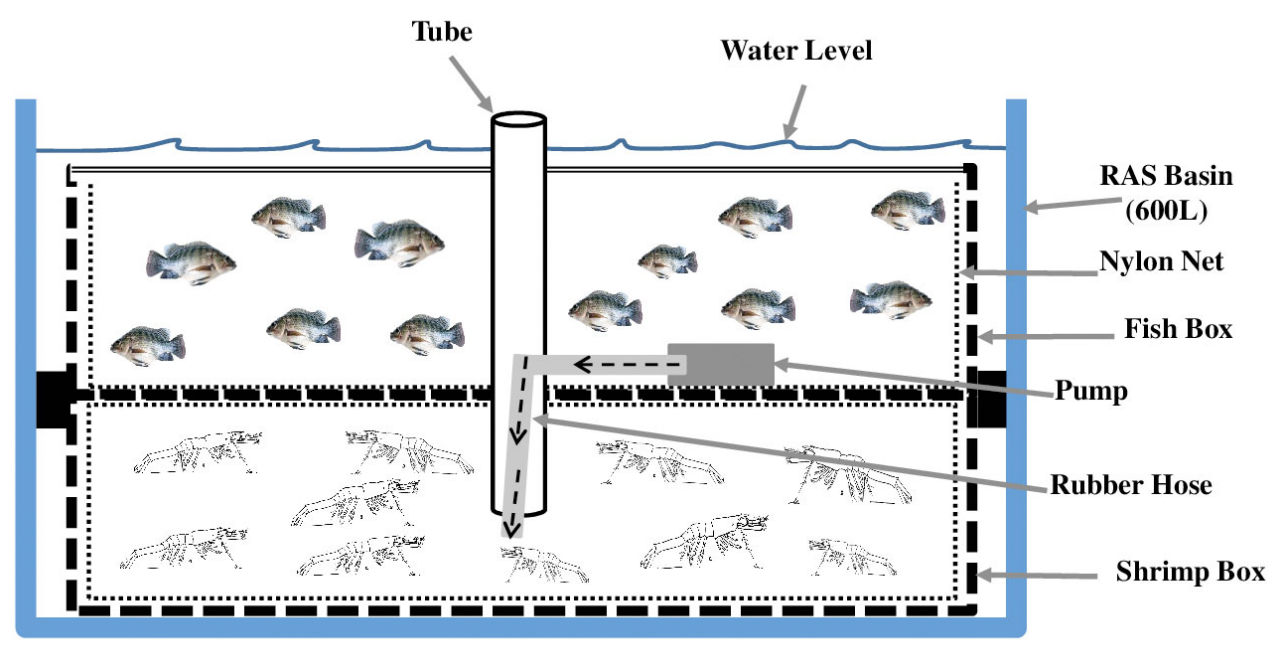

tre for Polar and Marine Research in Bremerhaven, Germany. Shrimp and red tilapia were acclimated separately to the experimental conditions (12-15 PSU and $28^{\circ} \mathrm{C}$ ) for $3 \mathrm{wk}$. During the acclimation period, red tilapia and shrimp were fed with commercial diets, TilapiCo PEARL EF (Coppens International) and CreveTec PL1000 (CreveTec), respectively, to satiation 4 times daily. The same diet was fed during the subsequent trial.

\section{Experimental design and culture technique}

All experiments were conducted in the ZAF facilities in a RAS under indoor conditions. Replicate culture units were constructed from 2 plastic boxes, each $60 \times 24 \times 35 \mathrm{~cm}(\mathrm{~L} \times \mathrm{W} \times \mathrm{H})$ in size (Fig. 1). The 2 boxes ( 1 replicate unit) were lined with $1 \mathrm{~mm}$ nylon net, placed one on top of the other, and tied together to avoid loss of shrimp, feed or faeces. A $40 \mathrm{~cm}$ long tube $(\varnothing 7 \mathrm{~cm})$ was inserted through a hole in the bottom of the top box to provide direct access to the bottom box, allowing administration of shrimp diets in the appropriate treatments (OS and FSD; see below). A $65 \mathrm{~cm}$ rubber hose connected to a small pump moved feces and uneaten food from the upper box to the bottom one. The initial experimental stocking densities were comparable to suggested commercial production systems (e.g. Akiyama \& Anggawa 1999, Fitzsimmons 2001, Tian et al. 2001, Hernández-Barraza et al. 2012, da Silva 2013, Schveitzer et al. 2013, Samocha et al. 2015, Perschbacher \& Stickney 2017), taking into consideration higher to super-intensive stocking densities. The upper box was stocked with 12 red tilapia $\left(2.6 \mathrm{~kg}\right.$ or 240 fish $\left.\mathrm{m}^{-3}\right)$, while the bottom box was stocked with 50 shrimp $(0.024 \mathrm{~kg}$ or 1000 shrimp $\mathrm{m}^{-3}$ ). All treatments were established in triplicate; thus in total 12 units were submerged into 3 tanks (600 l) connected to a RAS in a randomized manner (Fig. 1). Commercial diets were provided 2 times daily to a total of $5 \%$ of body weight for red tilapia and $10 \%$ of body weight for shrimp. Red tilapia diet (TilapiCo PEARL EF) contained 37\% crude protein and $10 \%$ crude lipid while shrimp diet (CreveTec Grower) contained $40 \%$ crude protein and $9 \%$ crude lipid. Feeding rates were adjusted after each weighing event. The shrimp in co-culture were supplied with waste diet and faeces from the red tilapia of the upper box. This mixture of waste diet and faeces contained on average $23 \%$ crude protein and $0.4 \%$ crude lipid. Four different treatments were applied with red tilapia fed commercial diet (treatment OF), and shrimp fed commercial diet in monoculture (OS) and unfed (FS) or co-fed (FSD) in co-culture with tilapia (Table 1). Light:dark phases were adjusted to $12: 12 \mathrm{~h}$. Aeration of the water was continuously provided using compressed air. The experiment was run for $84 \mathrm{~d}$ from June to August 2015. Salinity, temperature, dissolved oxygen, $\mathrm{pH}$ and ammonia were continuously monitored during the experiment as a normal routine for RAS.

\section{Growth performance and nutrient utilization indices}

The weight of the fish was determined at the beginning of the experiment and bi-weekly thereafter. Shrimp weight was initially determined and thereafter only every month during the experiment to avoid stress due to excessive handling and disturbance.

Shrimp and fish weight gain (WG), shrimp hepatosomatic index (HSI), specific growth rate (SGR), sur- 
Table 1. Treatment and feeding conditions in the mono- and co-culture experiment with whiteleg shrimp Litopenaeus vannamei and red Nile tilapia Oreochromis niloticus in a recirculating aquaculture system. BW: body weight, na: not applicable

\begin{tabular}{|c|c|c|c|c|c|}
\hline Treatment & Code & (n) & $\begin{array}{c}\text { Tilapia } \\
\text { Feed }\end{array}$ & (n) & $\begin{array}{c}\text { Shrimp } \\
\text { Feed }\end{array}$ \\
\hline Monoculture fish & OF & 12 & Commercial diet at $5 \%$ of $\mathrm{BW}$ & 0 & na \\
\hline Monoculture shrimp & OS & 0 & na & 50 & Commercial diet at $10 \%$ of BW \\
\hline Co-culture (fish+shrimp), shrimp unfed & FS & 12 & Commercial diet at $5 \%$ of BW & 50 & Leftover feed, fish faeces \\
\hline Co-culture (fish+shrimp), shrimp co-fed & FSD & 12 & Commercial diet at $5 \%$ of BW & 50 & $\begin{array}{l}\text { Commercial diet at } 2.5 \% \text { of BW, } \\
\text { leftover feed and fish faeces }\end{array}$ \\
\hline
\end{tabular}

vival rate $(\mathrm{SR}, \%)$, feed conversion ratio (FCR), protein efficiency ratio (PER) and protein productive value (PPV) were calculated as follows:

$\mathrm{SR}=($ Final number of shrimp juveniles / Initial number of shrimp juveniles) $\times 100$

WG = Final body weight (g) - Initial body weight (g) (2)

HIS $=[$ Hepatopancreas weight $(\mathrm{g}) /$ Total body weight $(g)] \times 100$

$\mathrm{SGR}=[(\ln \mathrm{FBW}-\ln \mathrm{IBW}) / t] \times 100$

(where FBW is final body weight $(\mathrm{g})$; IBW is initial body weight $(\mathrm{g})$; $t$ is time in days)

FCR $=$ Total weight of feed consumed /

Wet weight gain

PER = Weight gain $(\mathrm{g}) /$ Protein fed $(\mathrm{g})$

$\mathrm{PPV}=[$ Protein gain $(\mathrm{g}) /$ Protein intake $(\mathrm{g})] \times 100$

\section{Chemical composition of fish and shrimp}

At the beginning of the experiment, a randomly pooled sample of 5 red tilapia and 12 shrimp was collected and stored at $-20^{\circ} \mathrm{C}$ for determination of the initial whole-body proximate composition. At the termination of the feeding trial, 3 red tilapia and 3 shrimp were randomly selected from each tank to determine the proximate whole body composition. The animals were blended and homogenized, oven-dried, ground and stored at $-20^{\circ} \mathrm{C}$ for subsequent analysis. The proximate compositions of red tilapia and shrimp samples were determined according to AOAC (1995). Dry matter was determined after oven drying $\left(105^{\circ} \mathrm{C}\right)$ for $3 \mathrm{~h}$ (Drying Oven, GE-174, Memmert) (AOAC 1995, method no. 930.15). Ash was measured by incineration at $550^{\circ} \mathrm{C}$ for $12 \mathrm{~h}$ (Thermo Scientific Heraeus M 110 Muffle Furnace) (AOAC 1995, method no. 942.05). Crude protein was determined by the microKjeldhal method, N\% × 6.25 (using a Kjeltech autoanalyser, Model 1030, Tecator) (AOAC 1995, method no. 984.13) and crude fat by Soxhlet extraction with diethyl ether $\left(40-60^{\circ} \mathrm{C}\right)$ (Soxtec System HT6, Tecator) (AOAC 1995, method no. 920.39).

\section{Total RNA isolation and cDNA synthesis}

Total RNA was isolated from the abdominal muscles of shrimp ( $\mathrm{n}=3$ per tank and per treatment) using a GeneJET RNA Purification Kit including DNase I digestion to eliminate residual genomic DNA following the manufacturer's protocol (Thermo Scientific, no. K0731). The integrity of total RNA was assessed by inspection of the ribosomal RNA bands (18S and 28S) in ethidium bromide-stained 1.5\% agarose gels under ultraviolet (UV) light. RNA purity was determined by measuring the 260/280 nm optical density (OD) ratio using a Nanodrop device (UV-visible spectrophotometer Q5000; Quawell). Total RNA samples with clear intact ribosomal bands and high RNA ratios (A260/A280 21.8) were used for cDNA synthesis. The RNA was reverse transcribed using RevertAid H Minus Reverse Transcriptase, which is a genetically modified Moloney Murine Leukemia Virus reverse transcriptase (M-MuLV RT) (Thermo Scientific, no. EP0451), following the protocol described by Mahfouz et al. (2015).

\section{Expression analysis of $c M n S O D$ and GPX genes by qPCR}

Relative expression of $C M n S O D$ and $G P X$ genes was determined using the Step One Plus real time PCR system (Applied Biosystems). Gene-specific primers were designed by Primer 5.0 software (PREMIER Biosoft International) based on published sequences of Litopenaeus vannamei (Table 2). Amplifications were performed in triplicate in a 96-well plate in a $20 \mu \mathrm{l}$ reaction volume containing $10 \mu \mathrm{l}$ of 2× Maxima SYBR Green/ROX qPCR Master Mix (Thermo Scientific, no. K0221), $0.5 \mu$ of each primer 
Table 2. Oligonucleotide primer sequences for real-time PCR used for detection of relative gene expression in mono- and co-cultured whiteleg shrimp Litopenaeus vannamei

\begin{tabular}{|llccc|}
\hline Gene & Primer sequence $\left(5^{\prime}-3^{\prime}\right)$ & $\begin{array}{c}\text { Accession } \\
\text { no. }\end{array}$ & Position & $\begin{array}{l}\text { Size } \\
\text { (bp) }\end{array}$ \\
\hline \multirow{2}{*}{ CMnSOD } & $\begin{array}{l}\text { F: AATTGGAGTGAAAGGCTCTGGCT } \\
\text { R: ACGGAGGTTCTTGTACTGAAGGT }\end{array}$ & DQ005531 & $583-735$ & 153 \\
GPX & $\begin{array}{l}\text { F: AGGGACTTCCACCAGATG } \\
\text { R: CAACAACTCCCCTTCGGTA }\end{array}$ & AY973252 & $237-353$ & 117 \\
& $\begin{array}{l}\text { F: GCCCATCTACGAGGGATA } \\
\text { R: GGTGGTCGTGAAGGTGTAA }\end{array}$ & AF300705 & $522-642$ & 121 \\
& & & & \\
\hline
\end{tabular}

same temperature under permanent agitation. The reaction was terminated with $500 \mu$ l of $10 \%$ trichloroacetic acid (TCA) and cooling on ice. The tubes were centrifuged at $20000 \times g(10 \mathrm{~min}$, $4^{\circ} \mathrm{C}$ ), and the absorbance of the supernatant was measured at $366 \mathrm{~nm}$ in a spectrophotometer. Enzyme assays of each shrimp were run in triplicate and controls in duplicate. Controls received the samples after the addition of TCA. The activity $\left(\Delta \mathrm{E}_{366} \mathrm{~min}^{-1}\right)$ was normalized to $1 \mathrm{~g}$ (fresh weight, fw) of tissue $\left(\Delta \mathrm{E}_{366} \mathrm{~min}^{-1} \mathrm{~g}_{\mathrm{fw}}^{-1}\right)$.

The activities of trypsin, leucine-exopeptidase, and alkaline phosphatase were also measured photometrically. Ten to fifty $\mu$ of the sample were added to $950-990 \mu \mathrm{l}$ of Tris/HCl-buffer $\left(0.1 \mathrm{~mol} \mathrm{l}^{-1}, \mathrm{pH} 8.0\right.$ at $27^{\circ} \mathrm{C}$ ). The substrate N-benzoyl-L-arginin-4nitroanilid-hydrochlorid (L-BAPA, Applichem, A 5030) was used for the determination of trypsin activity after Erlanger et al. (1961). It was first dissolved in dimethylsulphoxide (DMSO) at a concentration of $50 \mathrm{mmol} \mathrm{l}^{-1}$. Then, $20 \mu \mathrm{l}$ of this solution were added to the reaction mixture, yielding a final substrate concentration of $1 \mathrm{mmol} \mathrm{l}^{-1}$ and a DMSO concentration of $2 \%(\mathrm{v} / \mathrm{v})$. Exopeptidase activity was assayed with the substrate leucin-p-nitroanilide (Sigma, L9125) as described above for trypsin activity. Alkaline phosphatase was measured with the substrate p-nitrophenylphosphate (Sigma, N4645). This substrate was dissolved in demineralized water instead of DMSO and applied at a final concentration of $1 \mathrm{mmol} \mathrm{l}^{-1}$ as described above.

Hydrolysis of the substrates liberated the yellowish 4-nitroaniline and 4-nitrophenol, respectively. The increase in absorbance at $405 \mathrm{~nm}$ was continuously measured for $180 \mathrm{~s}$. One unit of enzyme activity was defined as $1 \mu \mathrm{mol}$ substrate liberated in $1 \mathrm{~min}$ at $27^{\circ} \mathrm{C}$ $\left(U=\mu \mathrm{mol} \mathrm{min}^{-1}\right)$. The enzyme activity was normalized for $1 \mathrm{~g}$ of fresh weight of the midgut gland and presented as specific enzyme activity $U \mathrm{~g}^{-1}{ }_{\mathrm{fw}}$.

\section{Gel electrophoresis}

A non-degrading polyacrylamide gel electrophoresis (substrate-PAGE) after García-Carreño et al. (1993) was conducted on mini gels $(8 \times 9.5 \times 0.75 \mathrm{~cm})$ to separate the proteins and active enzymes of the crude extracts. Five $\mu$ l of each sample were mixed $(1 \%[\mathrm{w} / \mathrm{v}]$ in buffer) and incubated for $30 \mathrm{~min}$ at the 
with the same amount of sample buffer $\left(0.125 \mathrm{~mol} \mathrm{l}^{-1}\right.$ Tris/HCl [pH 6.8], $0.2 \mathrm{mg} \mathrm{ml}^{-1}$ bromphenol blue, $3 \%$ [v/v] glycerol, $4 \%$ sodium dodecyl sulphate [SDS]) and loaded onto $12 \%$ polyacrylamide gels. The samples were not treated with mercaptoethanol and were not heated. Thus, the proteins did not degenerate but remained active. Roti-Mark Standard (Roth, T851.2) was used as protein size marker. Separation was performed in a Hoefer SE 260 device for $1.5 \mathrm{~h}$ at a maximum of $300 \mathrm{~V}$ and $15 \mathrm{~mA}$, at $4{ }^{\circ} \mathrm{C}$. The electrophoresis buffer was $0.025 \mathrm{~mol}{ }^{-1}$ Tris $/ \mathrm{HCl}, 0.192 \mathrm{~mol}$ $1^{-1}$ glycerol and $0.1 \%$ (w/v) SDS, pH 8.3.

Gels for protease activity (García-Carreño et al. 1993) were incubated for 30 min on ice in a casein solution (3\% [w/v] in $0.1 \mathrm{~mol} \mathrm{l}^{-1}$ Tris/ $\left.\mathrm{HCl}, \mathrm{pH} 8\right)$. Thereafter, the gels were incubated for another $30 \mathrm{~min}$ at room temperature to increase the hydrolytic activity of the separated enzymes. The gel was then washed thoroughly with demineralized water and then incubated overnight in Coomassie solution and de-stained next day. The gels showed a blue background and pale bands where endopeptidases were active. Photographs of the gels were made with the BioRad Gel Doc EZ Imager and processed with the program Image Lab.

\section{Statistical analysis}

Statistical analysis was conducted using a statistical package (SPSS 13.0 for Windows). Before analysis, data in the form of percentages were transformed (arcsine of the square root) to obtain normality and homogeneity but are presented as non-transformed percentages. One-way analysis of variance (ANOVA) was used to test for a significant difference $(p<0.05)$ between treatments for measured parameters. Duncan's multiple range test was used to compare differences between treatment means when significant $F$ values were observed (Duncan 1955). The effects of the co-culture on antioxidant-related gene expression were assessed by 1-way ANOVA followed by Tukey's multiple comparisons test using GraphPad Prism version 6.00 for Windows (www.graphpad. com). Values of $\mathrm{p}<0.05$ were considered to be statistically significant. Mean values are given with SEM unless otherwise stated.

\section{RESULTS}

\section{Growth performance and nutrient utilization}

Growth performance of red tilapia in monoculture (treatment OF) was significantly ( $<<0.05)$ higher as indicated by FBW and SGR compared with red tilapia in co-culture (FSD and FS) treatments (Table 3). The shrimp in co-culture which were co-fed commercial diet (FSD) recorded higher values of FBW, WG and SGR compared with shrimp in mono- (OS) and unfed co-culture (FS), but the SR of FSD shrimp was significantly lower than those of OS and FS shrimp. PER and PPV for red tilapia were significantly $(p<0.05)$ lower in monoculture than in co-culture. Furthermore, the FCR for red tilapia were significantly ( $\mathrm{p}<$ 0.05 ) lower (indicating the most efficient use of feed) in co-culture than in monoculture units. Shrimp FCR was significantly $(p<0.05)$ lower in the FSD treatment compared with the shrimp in monoculture (OS) and shrimp in the FS treatment. PER of shrimp was significantly higher $(\mathrm{p}<0.05)$ in the FSD treatment than in all other treatments.

Table 3. Growth performance for red Nile tilapia Oreochromis niloticus and whiteleg shrimp Litopenaeus vannamei culture in either monoculture or co-culture systems (see Table 1 for treatments). Values are mean \pm SD. Values with different superscripts in the same rows (same species) are significantly different from the monoculture treatment $(\mathrm{p} \leq 0.05)$. IBW: initial body weight; FBW: final body weight; SR: survival rate; WG: weight gain; SGR: specific growth rate; FCR: feed conversion ratio; PER: protein efficiency ratio; PPV: protein productive value (see Eqs. 1-7 in the main text for calculations of the growth indicators)

\begin{tabular}{|c|c|c|c|c|c|c|}
\hline Growth indicator & Tilapia OF & Tilapia FS & Tilapia FSD & Shrimp OS & Shrimp FS & Shrimp FSD \\
\hline IBW (g) & $10.92 \pm 2.59$ & $10.92 \pm 2.59$ & $10.92 \pm 2.59$ & $0.024 \pm 0.001$ & $0.024 \pm 0.001$ & $0.024 \pm 0.001$ \\
\hline FBW (g) & $173.65 \pm 5.46^{\mathrm{a}}$ & $139.16 \pm 1.80^{\mathrm{b}}$ & $130.33 \pm 4.47^{c}$ & $9.62 \pm 1.06^{\mathrm{c}}$ & $11.32 \pm 1.48^{\mathrm{b}}$ & $13.02 \pm 2.38^{\mathrm{a}}$ \\
\hline SR $(\%)$ & $79.17 \pm 6.24^{\mathrm{b}}$ & $91.67 \pm 4.16^{\mathrm{a}}$ & $81.25 \pm 2.08^{b}$ & $81.5 \pm 2.50^{\mathrm{a}}$ & $78.50 \pm 4.50^{\mathrm{b}}$ & $46.00 \pm 7.00^{\mathrm{c}}$ \\
\hline WG $(\mathrm{g})$ & $162.73 \pm 5.22^{\mathrm{a}}$ & $128.24 \pm 3.94^{\mathrm{b}}$ & $119.41 \pm 3.11^{\mathrm{c}}$ & $9.60 \pm 1.21^{\mathrm{c}}$ & $11.30 \pm 3.25^{\mathrm{b}}$ & $13.00 \pm 5.27^{\mathrm{a}}$ \\
\hline SGR & $2.38 \pm 0.19^{\mathrm{a}}$ & $2.16 \pm 0.20^{\mathrm{a}}$ & $2.09 \pm 0.08^{b}$ & $6.60 \pm 0.06^{b}$ & $6.76 \pm 0.17^{b}$ & $6.90 \pm 0.38^{a}$ \\
\hline FCR & $1.43 \pm 0.23^{\mathrm{c}}$ & $1.56 \pm 0.21^{b}$ & $1.67 \pm 0.24^{\mathrm{a}}$ & $1.31 \pm 0.12^{\mathrm{a}}$ & $1.20 \pm 0.01^{\mathrm{a} \Psi}$ & $0.81 \pm 0.23^{\text {c๘t }}$ \\
\hline PER & $2.24 \pm 0.21^{\mathrm{a}}$ & $1.42 \pm 0.35^{\mathrm{b}}$ & $1.41 \pm 0.23^{\mathrm{b}}$ & $1.83 \pm 0.24^{\mathrm{b}}$ & $0.16 \pm 0.01^{\mathrm{cf}}$ & $3.14 \pm 0.35^{\mathrm{a} \Psi \mp}$ \\
\hline PPV & $34.20 \pm 2.30^{\mathrm{a}}$ & $23.26 \pm 2.51^{\mathrm{b}}$ & $26.97 \pm 1.89^{b}$ & $26.97 \pm 1.35^{\mathrm{b}}$ & $2.55 \pm 0.65^{\mathrm{c} \mp}$ & $47.88 \pm 1.23^{\mathrm{a} \Psi \mathrm{t}}$ \\
\hline
\end{tabular}



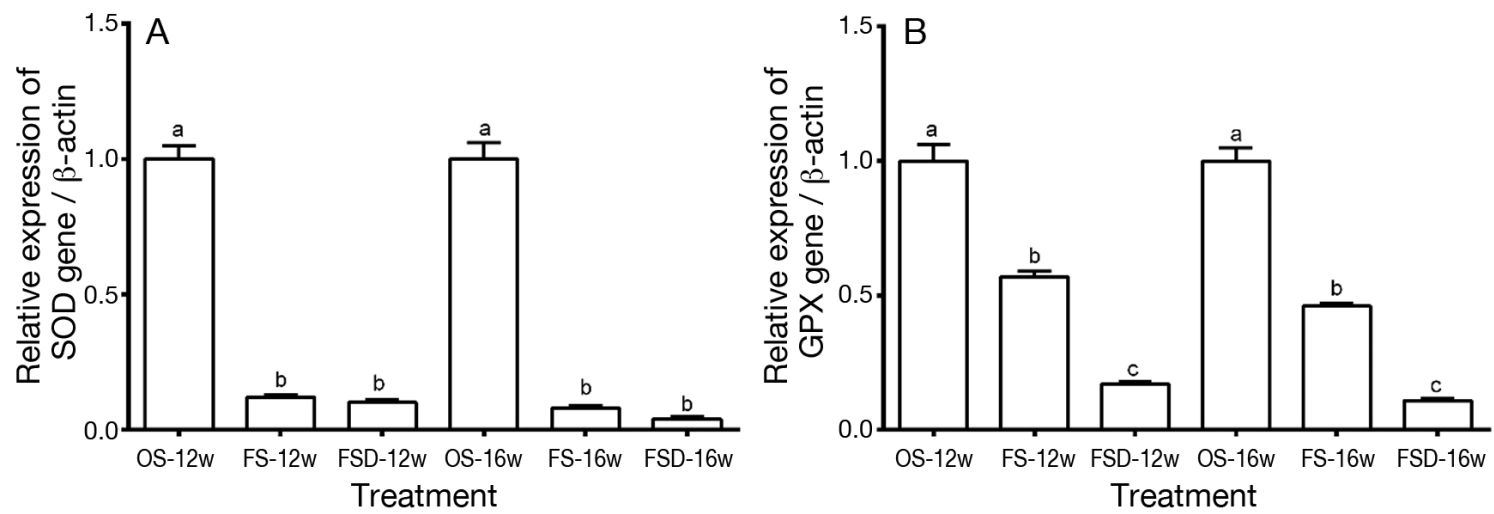

Fig. 2. Real-time quantitative PCR analysis of the relative expression of the genes (A) $C M n S O D$ and (B) GPX (as the amount of the reference gene $\beta$-actin, dimensionless) in whiteleg shrimp Litopenaeus vannamei after $12 \mathrm{wk}(12 \mathrm{w})$ and $16 \mathrm{wk}(16 \mathrm{w})$ in monoculture (OS) fed commercial shrimp diet (10\% body weight), shrimp in co-culture with Nile tilapia Oreochromis niloticus but unfed (FS), shrimp in co-culture co-fed on commercial shrimp $(2.5 \%)$ diet (FSD). Data are mean + SEM $(n=9$ in triplicate).

Means with different superscripts are significantly different from the monoculture treatment $(\mathrm{p} \leq 0.05)$

\section{Effect of co-culture on gene expression of $\mathrm{cMnSOD}$ and $G P X$}

Relative $C M n S O D$ gene expression was significantly downregulated in both co-culture unfed shrimp (FS) $(0.12 \pm 0.01, \mathrm{p} \leq 0.0001)$ and co-cultured co-fed shrimp (FSD) $(0.10 \pm 0.01, \mathrm{p} \leq 0.0001)$ as compared to shrimp in monoculture (OS) (1.00 \pm 0.05$)$ after $12 \mathrm{wk}$ of co-culturing (Fig. 2A). No significant difference was present in the relative expression of the $c M n$ SOD gene between FS and FSD shrimp after $12 \mathrm{wk}$ of co-culturing. After co-culturing for $16 \mathrm{wk}$, the $c M n$ $S O D$ gene showed a similar change in relative expression level as at $12 \mathrm{wk}$ in co-culture, but with a slightly lower expression in FS $(0.08 \pm 0.009)$ and FSD $(0.04 \pm 0.008)$ groups (Fig. 2A).

The GPX gene was significantly downregulated in both FS $(0.57 \pm 0.02, \mathrm{p} \leq 0.0001)$ and FSD $(0.17 \pm 0.01$, $\mathrm{p} \leq 0.0001)$ as compared to shrimp in the control

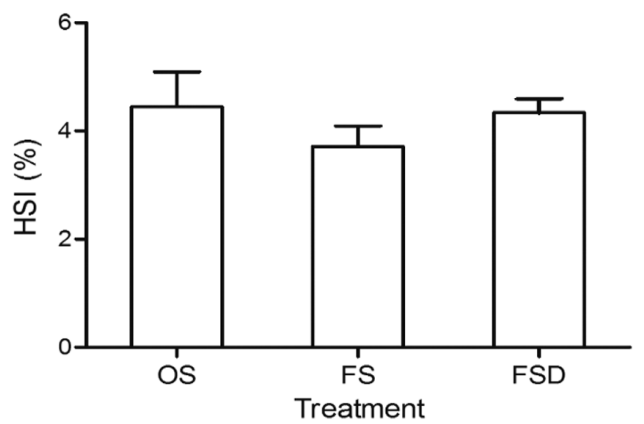

Fig. 3. Hepatosomatic indices (HSI) of whiteleg shrimp Litopenaeus vannamei which were randomly selected for enzyme analysis. Data are mean + SEM $(n=8)$. The values did not differ significantly between treatments (ANOVA, $\mathrm{p}=$ $0.4917, \mathrm{n}=8$ ). See Table 1 for treatment details group (1.00 \pm 0.06$)$ after $12 \mathrm{wk}$ in co-culture (Fig. 2B). Expression of the GPX gene in the FS group was significantly higher than in the FSD group (i.e. shrimp monoculture: $p \leq 0.0001)$. Similar results were obtained after $16 \mathrm{wk}$ in co-culture, but with a slightly lower expression in FS $(0.46 \pm 0.01)$ and FSD $(0.11 \pm$ 0.009) as compared to $12 \mathrm{wk}$ co-culture (Fig. 2B).

\section{Hepatosomatic index}

The HSI of shrimp ranged from $3.71 \pm 1.08$ in the FS treatment to $4.45 \pm 0.65$ in the OS treatment (Fig. 3), but the values were not statistically significant between treatments.

\section{Enzyme activities}

Total proteolytic activity did not differ significantly between treatments (OS: $112.2 \pm 25.9 \Delta \mathrm{E}_{366} \mathrm{~min}^{-1}$ $\mathrm{g}_{\mathrm{fw}}^{-1}, \mathrm{FS}: 97.8 \pm 23.1 \Delta \mathrm{E}_{366} \mathrm{~min}^{-1} \mathrm{~g}_{\mathrm{fw}}^{-1}$, FSD: $92.3 \pm$ $48.7 \Delta \mathrm{E}_{366} \mathrm{~min}^{-1} \mathrm{~g}^{-1}{ }_{\mathrm{fw}}$; ANOVA $\mathrm{p}=0.5405$, Fig. $4 \mathrm{~A}$ ).

The average specific trypsin activities differed between the treatments (ANOVA, $\mathrm{p}=0.0058$, Fig. 4B). The trypsin activity in FSD amounted to $15.49 \pm 2.42 \mathrm{U}$ $\mathrm{g}^{-1} \mathrm{fw}$ and was significantly higher than in OS (9.87 \pm $3.60 \mathrm{U} \mathrm{g}_{\mathrm{fw}}^{-1}, \mathrm{q}=4.704, \mathrm{p}<0.01$ ) as well as in FSD $\left(10.64 \pm 3.68 U^{-1} \mathrm{fw}, \mathrm{q}=4.20, \mathrm{p}<0.05\right)$. Differences between OS and FS were not significant $(q=0.6501)$.

The specific leucine aminopeptidase activities showed no significant differences between treatments (OS: $1.82 \pm 0.59 U^{-1}$ g $_{\text {fw }}$ FS: $1.04 \pm 0.40 U$ $\mathrm{g}_{\mathrm{fw}}^{-1}, \mathrm{FSD}: 1.63 \pm 0.89 \mathrm{U} \mathrm{g}_{\mathrm{fw}}^{-1}$, ANOVA $\mathrm{p}=0.0785$, Fig. 4C). 

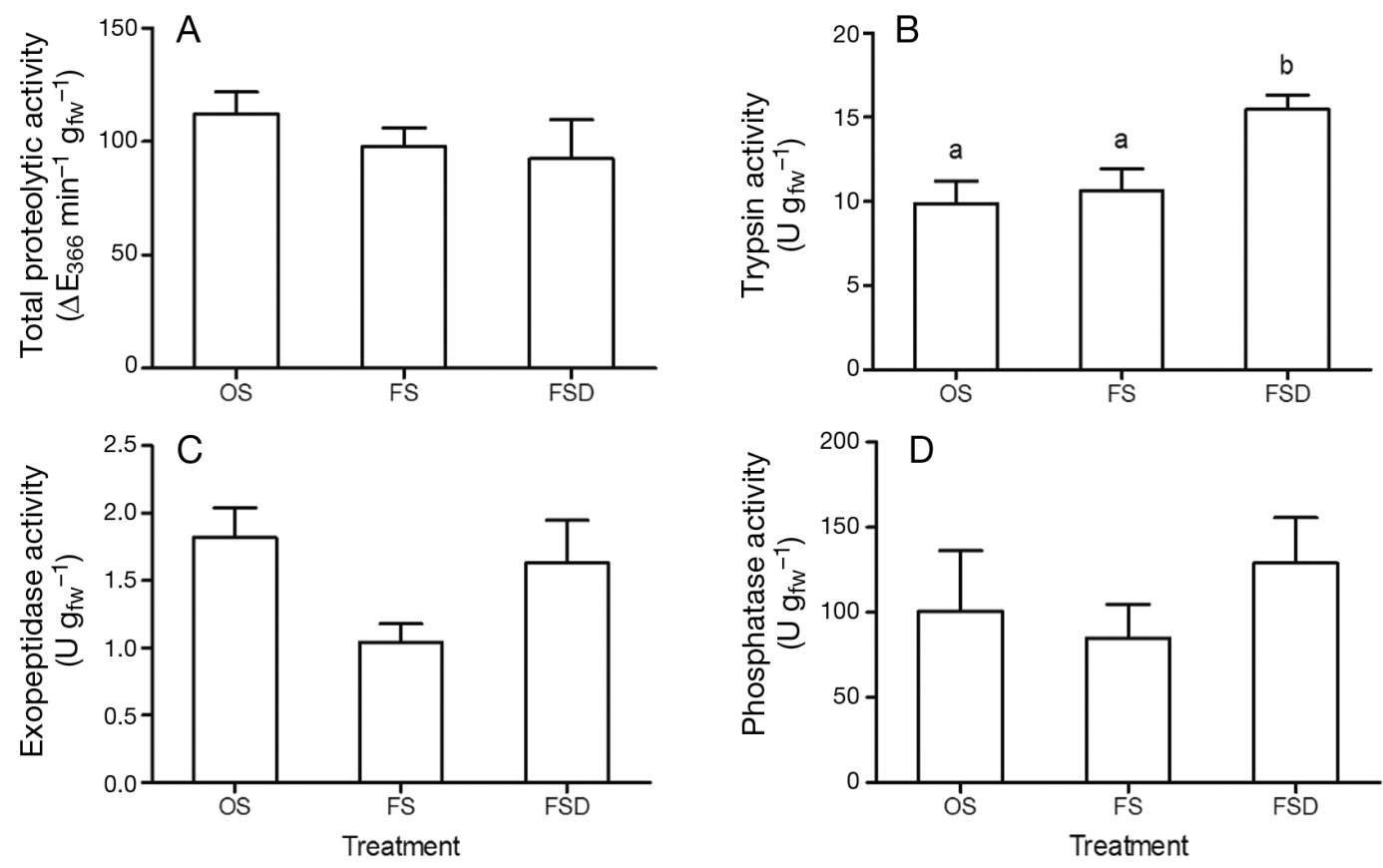

Fig. 4. Specific activities of (A) total proteolytic activity, (B) trypsin, (C) leucine aminopeptidase and (D) alkaline phosphatase; fw: fresh weight. Data are means + SEM $(n=8)$. Different letters above columns indicate significant differences $(p \leq 0.05)$ between treatments (see Table 1 for treatment details)

The specific phosphatase activities were also not significantly different between the treatments (OS: $100.61 \pm 94.39 U^{-1}{ }_{\text {fw }}$, FS: $84.91 \pm 56.80 U^{-1}{ }_{\text {fw }}$, FSD: $129.08 \pm 75.29 U^{-1}{ }^{-1}$ iwi ANOVA $p=0.4544$, Fig. 4D).

\section{Electrophoresis}

The casein-loaded gels showed distinct activity bands in an apparent size range of 14 to $40 \mathrm{kDa}$ (Fig. 5). Six major bands, 3 of them around $20 \mathrm{kDa}$ and the other 3 at about 24,30 and $40 \mathrm{kDa}$, were expressed by all individuals (except FS 2.1, which lacked the $40 \mathrm{kDa}$ band, Fig. 5B). Another 6 minor bands showed a more variable appearance. Some samples, such as OS 3.1 and OS 3.2, showed 2 distinct bands in the range of 14 to $16 \mathrm{kDa}$ (Fig. 5A). These bands were less distinct or absent in other individuals. Other minor bands were present at about 21, 25, 28 and $29 \mathrm{kDa}$. Although variations appeared in the samples within each treatment, no significant differences were seen between the treatments (cluster analysis: no grouping of samples, results not shown in the graph).

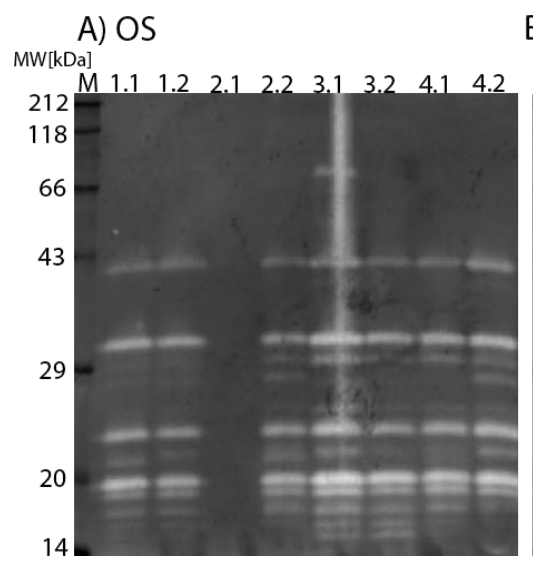

B) FS

C) FSD
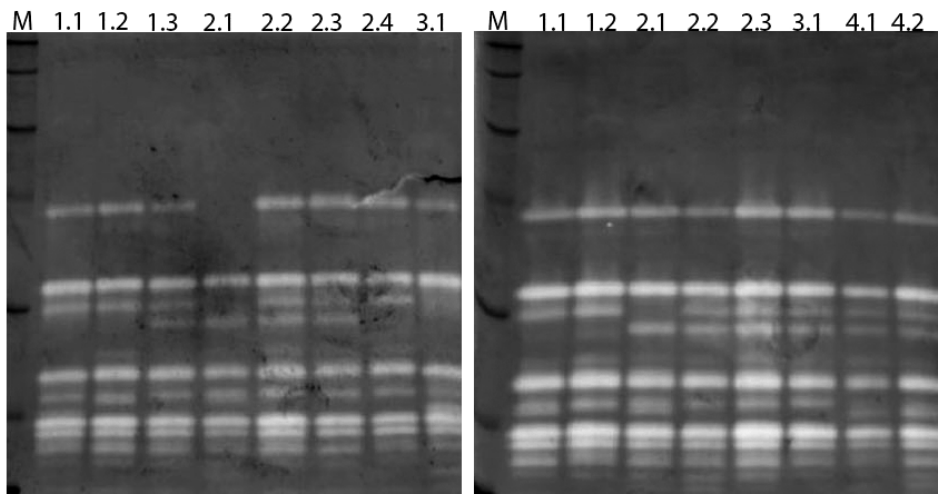

Fig. 5. Protease activity in whiteleg shrimp Litopenaeus vannamei in all treatments: (A) OS, (B) FS and (C) FSD (see Table 1 for treatment details). MW is the marker showing the molecular weight in $\mathrm{kDa}$. Bands indicate the protease activity by hydrolyzed casein, where lighter bands indicate higher activity. The numbering of lanes identifies individual shrimp from each treatment. Note that sample 2.1 in all treatments indicates possible sample degradation or other loss 


\section{DISCUSSION}

Nile tilapia and whiteleg shrimp are 2 commercially important tropical aquaculture species suited to RAS and pond culture systems. In the current study, we evaluated unfed and co-fed red tilapiashrimp co-cultures in a RAS and determined antioxidant gene expression (as an indicator of stress), digestive enzyme activities, growth and condition parameters as indicators of nutritional status. Significantly down-regulated antioxidant expression, combined with optimal growth and nutritional status indicators clearly showed that the biotic and abiotic conditions in co-culture suited shrimp better than monoculture conditions.

A multitude of stressors, such as temperature stress, inappropriate salinity, $\mathrm{pH}$ or redox potential, starvation, flight response and chemical and biological agents result in increased production of ROS in aquaculture species, including shrimp (Castex et al. 2010, Qiu et al. 2011, Duan et al. 2015, Wang et al. 2015, Robles-Romo et al. 2016). An enzymatic AD system including the enzymes GPX, SOD and CAT is activated to reduce high ROS levels in the tissues (Kassahn et al. 2009, García-Triana et al. 2010, Sheikhzadeh et al. 2012). Results of the current study show a significant downregulation in the expression of both antioxidant genes, $C M n S O D$ and $G P X$, in shrimp co-culture. This result is valid both for shrimp in unfed co-culture (feeding only on tilapia waste, FS) and shrimp in co-fed co-culture (receiving $25 \%$ of the normal ration of shrimp diet to supplement tilapia waste diet, FSD) and indicates that either the fed shrimp experienced much lower stress in coculture treatments or that they were so stressed that they were energetically incapable of eliciting a stress response. The latter can be disregarded given that the shrimp in these treatments exhibited excellent growth rates beyond those recorded in shrimp monoculture with a proven high-quality commercial shrimp diet. Additionally, the survival and condition of the shrimp as represented by the HSI $(4.16 \pm 1.29)$ indicated good health and nutritive state of the animals. The HSI values were in the same range as recently reported for healthy juvenile Litopenaeus vannamei (Wang et al. 2014). If the shrimp starved, even for only a few days, the HSI could have rapidly dropped below 2.5\% (Sánchez-Paz et al. 2007).

It is thus evident that abiotic parameters across treatments and interaction with tilapia did not stress the shrimp. Stress may be lower in co-culture treatments in particular due to a surfeit of diet in the form of tilapia faeces and some waste diet, or due to an improved nutritional budget or provision due to the presence of biowastes. The solid waste from tilapia faeces in the current study falls within the dietary protein requirements of Penaeidea reported by Allan \& Smith (1998), although it is below the protein content range of 27 to $50 \%$ in that study. Some components of the faecal matter, e.g. beneficial bacteria and pre-digestion of refractive elements by tilapia, increased the availability of vitamins and may have contributed to better growth rates of shrimp in the coculture treatments FS and FSD. Additionally waste of fish may provide certain nutrients or digestion regulators to shrimp which are vital to their metabolism. Survival rates in shrimp were higher when they were fed solid waste only, with the supplementary diet treatment FSD resulting in markedly poorer survival (Table 3). This remains unexplained in the context of the antioxidant enzyme expression results and growth data. We suggest that the low survival is related to escape of extremely small post-larvae (PLs) at the onset of the experiment, given that the recorded stress levels were low and, as implied by the HSI and argued below, the nutritional status was excellent in shrimp in the FSD treatment.

The activities of digestive enzymes also showed no indication of abnormal or impaired food utilization. The total proteolytic, exopeptidase and phosphatase activities showed no significant differences between treatments. Trypsin activities of the FSD-treatment were slightly but significantly elevated. Lee \& Lawrence (1982) first studied the activity of trypsin in whiteleg shrimp, and Lee et al. (1984) described the quantitative differences in relation to age and diet. Trypsin and chymotrypsin are responsible for 40 to over $60 \%$ of total protein digestion in penaeid shrimp (Galgani et al. 1984, 1985). Variable amounts of proteins and other ingredients in the diet can cause variations in trypsin activity, e.g. there is a significant interaction between the level of casein in food and trypsin (Le Moullac et al. 1997). Prolonged starvation of whiteleg shrimp entailed reduced activities of digestive enzymes, including trypsin, when activities were extrapolated for the total weight of the hepatopancreas. However, since the weight of the hepatopancreas decreased in the course of starvation, the specific activity ( $U \mathrm{mg}^{-1}$ of tissue) increased (Comoglio et al. 2004). In our experiment, shrimp within the FSD treatment showed significantly higher trypsin activities. These animals were fed with both highprotein shrimp and fish commercial diets and, thus, are considered least susceptible to starvation. Accordingly, the elevated trypsin activity is not caused by starvation and instead, as Lee et al. (1984) argued, 
is explained by medium and large shrimp exhibiting higher trypsin activities than small shrimp. Since the largest animals were present in the FSD treatment, the high trypsin activity in this group can simply be explained by the larger size of the animals rather than malnutrition or excess protein in the diet.

The electrophoresis patterns of proteins and active endopeptidases showed a widely similar appearance between specimens and treatments. All animals, except one, showed approximately 12 distinct activity bands on the native gel. Three bands, which appeared slightly below the $20 \mathrm{kDa}$ marker, represent the trypsin isoforms A, B and C (Klein et al. 1996, Sainz et al. 2004). The true molecular masses of these enzymes are 30 to $33 \mathrm{kDa}$. According to Sainz et al. (2005), all analysed individuals of our experiment belong to the same trypsin phenotype 1 (of 3) expressing all 3 trypsin isoforms. The similar expression patterns of endopeptidases in each of the 3 treatments indicate that the enzymatic capacity of the shrimp to utilize dietary proteins is not affected by the origin of food even if it largely consists of fish egesta.

Overall, the current study shows that co-culture of shrimp and red tilapia results in reduced levels of known stress indicators both in unfed and co-fed forms. Shrimp in co-culture maintained an excellent nutritional status resulting in significantly increased growth rates for shrimp, the high-value species in the system. The net supply of food was sufficient for both species even when only the fish were fed; however, reduced red tilapia growth rates in co-culture remain unexplained and need to be addressed. A slight benefit in terms of growth rate was observed in the case of cofeeding of shrimp. However, the commercial utility of co-feeding can be debated. Any growth benefit from co-feeding of shrimp must be balanced against increased diet cost. In this case, feeding at $25 \%$ of the commercial rate resulted in an approximately $15 \%$ increase in shrimp size, although shrimp total biomass was not increased. This is equivalent to an FCR of 1.6 for additional feed provided and additional growth as opposed to an FCR of 1.3 in monoculture, which indicates a comparatively inefficient use of diet. In cases where diet is extremely low cost, co-feeding may make economic sense but may undermine the environmental benefits of the co-culture in terms of resource efficiency and nutrient loss (Chopin et al. 2008). In sum, our results indicate that co-feeding is unnecessary in terms of commercial value, stress indicators or nutritional status, particularly when unfed co-culture offers the same benefits. Reduced levels of co-feeding may, however, be more efficient in terms of food use per gram benefit and should be further investigated.
Acknowledgements. We acknowledge the support of Christina Hörterer, Kai Lorkowski and Jan Köbel in assisting during system design and sampling. Z.Z.S. was funded by the Science and Technology Development Fund (STDF), Capacity Building Grant no. 12326, Ministry of Scientific Research, Egypt. We also thank the reviewers of the manuscript for their time and valuable suggestions.

\section{LITERATURE CITED}

Akiyama DM, Anggawa AM (1999) Polyculture of shrimp and tilapia in East Java. Tech Bull AQ 47-1999. American Soybean Association (ASA)

Allan GL, Smith DM (1998) Recent nutrition research with Australian penaeids. Rev Fish Sci 6:113-127

AOAC (Association of Official Analytical Chemistry) (1995) Official methods of analysis of the Association of Official Analytical Chemistry (16th edn). AOAC International, Washington, DC

Barraza CAH (2010) Analyses of productivity of Nile tilapia (Oreochromis niloticus), red tilapia (O. niloticus x $O$. mossambicus) and Pacific white shrimp (Litopenaeus vannamei) polyculture in a recirculating system. $\mathrm{PhD}$ dissertation, University of Arizona, Tucson, AZ

Castex M, Lemaire P, Wabete N, Chim L (2010) Effect of probiotic Pediococcus acidilactici on antioxidant defences and oxidative stress of Litopenaeus stylirostris under Vibrio nigripulchritudo challenge. Fish Shellfish Immunol 28:622-631

Chopin T, Buschmann AH, Halling C, Troell M and others (2001) Integrating seaweeds into marine aquaculture systems: a key toward sustainability. J Phycol 37:975-986

Chopin T, Robinson SMC, Troell M, Neori A, Buschmann $\mathrm{AH}$, Fang J (2008) Multitrophic integration for sustainable marine aquaculture. In: Jørgensen SE, Fath BD (eds) The encyclopedia of ecology. Elsevier, Oxford, p 2463-2475

Comoglio LI, Gaxiola G, Roque A, Cuzon G, Amin O (2004) The effect of starvation on refeeding, digestive enzyme activity, oxygen consumption, and ammonia excretion in juvenile white shrimp Litopenaeus vannamei. J Shellfish Res 23:243-249

Da Silva KR (2013) Nitrogen and phosphorus dynamics in the biofloc production of the Pacific white shrimp, Litopenaeus vannamei. J World Aquacult Soc 44:30-44

* Duan YF, Zhang JS, Dong HB, Wang Y, Liu QS, Li H (2015) Oxidative stress response of the black tiger shrimp Penaeus monodon to Vibrio parahaemolyticus challenge. Fish Shellfish Immunol 46:354-365

* Duncan DB (1955) Multiple range and multiple $F$ tests. Biometrics 11:1-42

Erlanger BF, Kokowsky N, Cohen W (1961) The preparation and properties of two new chromogenic substrates of trypsin. Arch Biochem Biophys 95:271-278

Fitzsimmons KM (2001) Polyculture of tilapia and penaeid shrimp. Glob Aquacult Advocate 4:43-44

Galgani ML, Benyamin Y, Ceccaldi HJ (1984) Identification of digestive proteinases of Penaeus kerathurus (Forskal.): a comparison with Penaeus japonicus. Comp Biochem Physiol 78B:355-361

Galgani ML, Benyamin Y, Van Wormhoudt A (1985) Purification, properties and immunoassays of trypsin from the shrimp Penaeus japonicus. Comp Biochem Physiol 81B: $447-452$ 
García-Carreño FL, Dimes LE, Haard NF (1993) Substrategel electrophoresis for composition and molecular weight of proteinases or proteinaceous proteinase inhibitors. Anal Biochem 214:65-69

García-Triana A, Zenteno-Savin T, Peregrino-Uriarte AB, Yepiz-Plascencia G (2010) Hypoxia, reoxygenation and cytosolic manganese superoxide dismutase ( $C M n S O D$ ) silencing in Litopenaeus vannamei: effects on $C M n S O D$ transcripts, superoxide dismutase activity and superoxide anion production capacity. Dev Comp Immunol 34: 1230-1235

Goda AMAS, Essa MA, Hassaan MS, Sharawy ZZ (2015) Bio economic features for aquaponic systems in Egypt. Turk J Fish Aquat Sci 15:531-538

*He J, Qiang J, Yang H, Xu P, Zhu ZX, Yang RQ (2015) Changes in the fatty acid composition and regulation of antioxidant enzymes and physiology of juvenile genetically improved farmed tilapia Oreochromis niloticus (L.), subjected to short-term low temperature stress. J Therm Biol 53:90-97

Henry-Silva GG, Maia CSP, Moura RST, Bessa JAP, Valenti WC (2015) Integrated multi-trophic culture of Nile tilapia (Oreochromis niloticus) and Amazon river prawn (Macrobrachium amazonicum) in brackish water. Arq Bras Med Vet Zootec 67:265-273

Hernández-Barraza C, Loredo J, Adame J, Fitzsimmons KM (2012) Effect of Nile tilapia (Oreochromis niloticus) on the growth performance of Pacific white shrimp (Litopenaeus vannamei) in a sequential polyculture system. Lat Am J Aquat Res 40:936-942

Hernández-Barraza C, López Cantú D, Loredo Osti J, Fitzsimmons K, Nelson S (2013) Productivity of polycultured Nile tilapia (Oreochromis niloticus) and Pacific white shrimp (Litopenaeus vannamei) in a recirculating system. Isr J Aquacult Bamidgeh 65:1-5

Kassahn KS, Crozier RH, Pörtner HO, Caley MJ (2009) Animal performance and stress: responses and tolerance limits at different levels of biological organization. Biol Rev Camb Philos Soc 84:277-292

Kim KY, Lee SY, Cho YS, Bang IC, Kim KH, Kim DS, Nam YK (2007) Molecular characterization and mRNA expression during metal exposure and thermal stress of cupper/zinc- and manganese-superoxide dismutase in disk abalone, Haliotis discus discus. Fish Shellfish Immunol 23:1043-1059

Klein B, Le Moullac G, Sellos D, Van Wormhoudt A (1996) Molecular cloning and sequencing of trypsin cDNAs from Penaeus vannamei (Crustacea, Decapoda): use in assessing gene expression during the moult cycle. Int $\mathrm{J}$ Biochem Cell Biol 28:551-563

* Le Moullac G, Klein B, Sellos D, Van Wormhoudt A (1997) Adaption of trypsin, chymotrypsin and $\alpha$-amylase to casein level and protein source in Penaeus vannamei (Crustacea Decapoda). J Exp Mar Biol Ecol 208:107-125

Lee PG, Lawrence AL (1982) A quantitative analysis of digestive enzymes in penaeid shrimp; influence of diet, age and species. Physiologist 25:241

Lee PG, Smith LL, Lawrence AL (1984) Digestive proteases of Penaeus vannamei Boone: relationship between enzyme activity, size and diet. Aquaculture 42:225-239

Livak KJ, Schmittgen TD (2001) Analysis of relative gene expression data using real-time quantitative PCR and the $2^{-\Delta \Delta C T}$ method. Methods 25:402-408

Lutz CG (2003) Polyculture: principles, practices, problems, and promise. Aquacult Mag 5:34-39
Mahfouz ME, Hegazi MM, El-Magd MA, Kasem EA (2015) Metabolic and molecular responses in Nile tilapia, Oreochromis niloticus during short and prolonged hypoxia. Mar Freshw Behav Physiol 48:319-340

McGinty AS, Alston DE (1987) Polyculture of all male tilapia hybrids with low densities of Macrobrachium rosenbergii. J Agric Univ P R 71:225-229

Milstein A, Ahmed AF, Masud OA, Kadir MA, Wahab MA (2006) Effects of the filter feeder silver carp and the bottom feeders mrigal and common carp on small indigenous fish species (SIS) and pond ecology. Aquaculture 258:439-451

*Muangkeow B, Ikejima K, Powtongsook S, Yi Y (2007) Effects of white shrimp, Litopenaeus vannamei (Boone), and Nile tilapia, Oreochromis niloticus L., stocking density on growth, nutrient conversion rate and economic return in integrated closed circulation system. Aquaculture 269:363-376

*Neori A, Chopin T, Troell M, Buschmann AH, Kraemer GP, Halling C (2004) Integrated aquaculture: rationale, evolution and state of the art emphasizing seaweed biofiltration in modern mariculture. Aquaculture 231:361-391

Perschbacher PW \& Stickney RR (eds) (2017) Tilapia in intensive co-culture. John Wiley and Sons, Chichester, p 82-94

Qiu J, Wang WN, Wang LJ, Liu YF, Wang AL (2011) Oxidative stress, DNA damage and osmolality in the Pacific white shrimp, Litopenaeus vannamei exposed to acute low temperature stress. Comp Biochem Physiol C Toxicol Pharmacol 154:36-41

Kobles-Romo A, Zenteno-Savin T, Racotta IS (2016) Bioenergetic status and oxidative stress during escape response until exhaustion in whiteleg shrimp Litopenaeus vannamei. J Exp Mar Biol Ecol 478:16-23

* Saborowski R, Sahling G, Navarrete del Toro MA, Walter I, García-Carreño FL (2004) Stability and effects of organic solvents on endopeptidases from the gastric fluid of the marine crab Cancer pagurus. J Mol Catal, B Enzym 30: 109-118

Sainz JC, García-Carreño FL, Hernández-Cortés P (2004) Penaeus vannamei isotrypsins: purification and characterization. Comp Biochem Physiol B Biochem Mol Biol 138:155-162

* Sainz JC, García-Carreño FL, Córdova-Murueta JH, CruzHernández P (2005) Whiteleg shrimp (Litopenaeus vannamei, Boone, 1931) isotrypsins: their genotype and modulation. J Exp Mar Biol Ecol 326:105-113

Samocha TM, Fricker J, Ali AM, Shpigel M, Neor A (2015) Growth and nutrient uptake of the macroalga Gracilaria tikvahiae cultured with the shrimp Litopenaeus vannamei in an Integrated Multi-Trophic Aquaculture (IMTA) system. Aquaculture 446:263-271

* Sánchez-Paz A, García-Carreño F, Hernández-López J, Muhlia-Almazán A, Yepez-Plascencia G (2007) Effect of short-term starvation on hepatopancreas and plasma energy reserves of the Pacific white shrimp (Litopenaeus vannamei). J Exp Mar Biol Ecol 340:184-193

Schveitzer R, Arantes R, Baloi MF, Costódio PFS, Arana LV, Seiffert WQ, Andreatta ER (2013) Use of artificial substrates in the culture of Litopenaeus vannamei (Biofloc System) at different stocking densities: effects on microbial activity, water quality and production rates. Aquacult Eng 54:93-103

Sheikhzadeh N, Tayefi-Nasrabadi H, Oushani AK, Enferadi $\mathrm{MH}$ (2012) Effects of Haematococcus pluvialis supple- 
mentation on antioxidant system and metabolism in rainbow trout (Oncorhynchus mykiss). Fish Physiol Biochem 38:413-419

Tian X, Li D, Dong D, Yan X, Qi Z, Liu G, Lu J (2001) An experimental study on closed-polyculture of penaeid shrimp with tilapia and constricted tagelus. Aquaculture 202:57-71

Wang M, Lu M (2016) Tilapia polyculture: a global review. Aquacult Res 47:2363-2374

Wang WN, Zhou J, Wang P, Tian TT and others (2009) Oxidative stress, DNA damage and antioxidant enzyme gene expression in the Pacific white shrimp, Litopenaeus vannamei when exposed to acute $\mathrm{pH}$ stress. Comp Biochem Physiol C Toxicol Pharmacol 150:428-435

Wang X, Li E, Qin JG, Wang S and others (2014) Growth, body composition, and ammonia tolerance of juvenile white shrimp Litopenaeus vannamei fed diets containing different carbohydrate levels at low salinity. J Shellfish Res 33:511-517

Wang XD, Wang SL, Li C, Chen K, Qin JG, Chen LQ, Li EC

Editorial responsibility: Alejandro Buschmann,

Puerto Montt, Chile
(2015) Molecular pathway and gene responses of the Pacific white shrimp Litopenaeus vannamei to acute low salinity stress. J Shellfish Res 34:1037-1048

*Wang YB (2007) Effect of probiotics on growth performance and digestive enzyme activity of the shrimp Penaeus vannamei. Aquaculture 269:259-264

Yang SP, Wu ZH, Jian JC (2013) Effect of marine red yeast Rhodosporidium paludigenum on antioxidant-related gene expression in Litopenaeus vannamei. Isr J Aquacult Bamidgeh 65:1-6

* Yuan D, Yang Y, Yakupitiyage A, Fitzsimmons K, Diana JS (2010) Effects of addition of red tilapia (Oreochromis spp.) at different densities and sizes on production, water quality and nutrient recovery of intensive culture of white shrimp (Litopenaeus vannamei) in cement tanks. Aquaculture 298:226-238

* Zhou J, Wang L, Xin Y, Wang WN, He WY, Wang AL, Liu Y (2010) Effects of temperature on antioxidant enzyme gene expression and stress protein response in white shrimp, Litopenaeus vannamei. J Therm Biol 35:284-289

Submitted: October 10, 2016 Accepted: May 23, 2017

Proofs received from author(s): July 14, 2017 